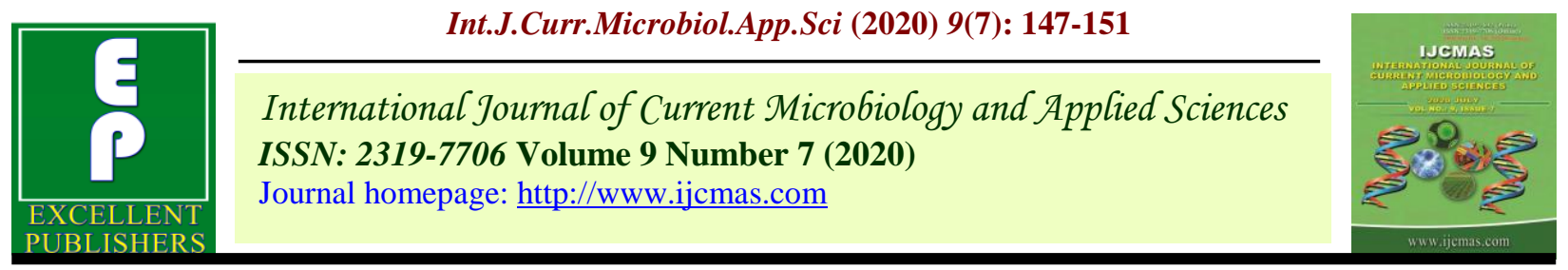

Original Research Article

https://doi.org/10.20546/ijcmas.2020.907.017

\title{
Constrains and Gap between Existing and Demanded Service by Farmers in Utilizing Krishi Yantra Seva Kendra of Chhattisgarh Plain
}

\author{
Sursen Kumar ${ }^{1^{*}}$ and Pramita Baghel ${ }^{2}$ \\ ${ }^{1}$ Department of Agri-Business and Rural Management, ${ }^{2}$ Department of Agriculture Economic, \\ College of Agriculture, IGKV, Raipur, India \\ *Corresponding author
}

\section{A B S T R A C T}

Keywords

Demand,

Constrains,

KYSK, Gap

Article Info

Accepted:

05 June 2020

Available Online:

10 July 2020
Mechanisation is playing vital role for the development of Agriculture. It helps to bring significant improvement in crop productivity. Chhattisgarh state has large number of marginal and small farmers having very poor economic condition. These categories of farmers, does not afford the machinery. To identify the constrains for augmenting gap between existing and demanded service by farmers. The study was confined to Chhattisgarh plains of 5 districts in 15 KYSK. There were 138 farmers studied those bringing the services of owners of KYSK. The sampled owners of KYSK reported that 100 per-cent demand of 60 per-cent farmers whereas demand for harvesting, threshing and winnowing of machinery was $66 \%$ that reported by almost owner of KYSK. The gap between demanding an supplied of machinery was found to be $6 \%$. Based empirical findings of the it is being that prices of the machines or rates should be fixed by the government .To avoid the discrimination of rates charges from farmer to farmers by owners of KYSK. Work payment should be there in due course of time.

\section{Introduction}

Farm mechanization has been helpful to bring about a significant improvement in agricultural productivity. Thus, there is strong need for mechanization of agricultural operations Custom hiring of farm machines was first introduced in Indian agriculture early decades of 19 th century when a 30 -inch (diameter) steam thresher was used for custom hiring. The machines were taken to about 10 different places working for 2 or 3 days at each place. Organized custom hiring to promote multi-farm use of agricultural machinery was made in mid-1960 when Agro-Industries Corporation (AIC) was established in the states.

In Chhattisgarh Custom hiring centres are opened under PPP mode since 2011-12 under Krishi Yantra Seva Kendra. Assistance on purchasing on machines is gives through subsidy. In general area and subarea purchasing of machine costing Rs. 25.00 
lakhs subsidy of Rs. 10.00 lakhs is provided and in subarea purchasing of machine costing Rs. 15.00 lakhs subsidy of Rs. 7.50 lakhs is also provided in the scheme as credit linked back ended subsidy. Custom hiring is an emerging concept in farming to facilitate adopting improved resource management among the like-minded farmers with commonality in the fanning practices. This system of resource sharing at a reduced cost to individual farmers are in vogue in some regions of the country with respect to farm machinery and implements, tube well water, marketing of the produce etc.(Ranade et al., 2006).

\section{Materials and Methods}

The service model on Krishi Yantra Seva Kendra (KYSK) was started in 2011-12. This service model is functioning in 27 districts of state. Totally, 569 KYSK across the agroclimatic zones and districts are sanctioned by the state Agriculture Engineering Department. There are 393 KYSK are being functioning in Chhattisgarh plain. Therefore, Chhattisgarh plain was selected for the study.

From the sampled districts 10 per cent owners of KYSK were undertaken to inquiries the details of the business performance of KYSK. Hence, there were 4, 4, 3, 3 and 1 KYSKs Raipur, Janjgir-Champa, Rajnandgoan, Dhamtari and Durg districts, respectively .

\section{Results and Discussion}

\section{Demand of machinery for agriculture operations}

The demand of machinery for agricultural operations varied from field preparation till harvesting of crop and it is worked out by percentage basis which is presented in Table 2. It shows that out of 15 sampled owner of KYSKs, 60 percentage where reported that
100 percentage demand of KYSK for field preparation while 20 percentage owner of KYSK reported that only 50 percentage demand of machinery for same operation well followed by 13 and $7 \%$ owner of KYSK reported that 75 percentage and 25 percentage demand for field preparation.

The season wise demand machinery through owner of KYSK was also worked out on order assigned to demand of 100, 75, 50 and 25 percentage during kharif and rabi season, which is presented in Table 3. It was found that 73.33, 20 and 6.67 percentage owners have reported that 100, 50 and 75 percentage demanded of machinery through KYSK, respectively. While the demand of machinery during rabi was $100,75,50$ and 25 percentage that reported by 53.33, 6.67, 33.33 and 6.67 percentage owners of KYSK, respectively.

\section{Gap of demand and supply of KYSK}

The gap between demand from beneficiaries farmers and supply of machines from KYSK was assessed through undertaken the perceptions from both side and ranged into four categories i.e. 75-100, 50-75, 25-50 and 0-25 per cent, which is given in Table 4. It reveals that sampled farmers were demand 86 per cent of machines under the range of 75100 per cent category. But, KYSK supplied the machines only up to 80 per cent, which indicates that there was a gap of 6 per cent under this range of demand and supply. Thus, it could be concluded that there is still gap between the demand and supply of KYSK.

\section{Major problems faced by owners of KYSK}

It reveals that irregular payment received from farmers was most common that reported by 73.33 percent farmers. While work on credit basis was next major problems faced by owners of KYSK, which reported by 60 percent farmers followed by 
lack of technical knowledge of machines acquire of driver, handling of machines and timely not available repair and maintenance facilities that reported by owners of KYSK $33.33,20$, and 13.33 percent, respectively in Fig 1.

Problems in hiring the machines from KYSK

The several question related with regards to hiring of machines by farmers from owners from owners of KYSK have asked and it is reported in Table 5.

The elicitation of farmers with regards to problems on timely non-availability of machine/implements from KYSK which was reported by 27.54 percent farmers.

While discrimination on rates charged by owners of KYSK from framer to framer that was another major problem faced by farmers and reported by $18.12 \%$ farmers.

Table.1 Numbers of KYSK and farmers of different selected Districts

\begin{tabular}{|c|l|c|c|c|}
\hline S. No. & District & Total KYSK & Selected KYSK & Selected farmers \\
\hline $\mathbf{1 .}$ & Rajnandgaon & 35 & 3 & 28 \\
\hline $\mathbf{2 .}$ & Raipur & 41 & 4 & 40 \\
\hline $\mathbf{3 .}$ & Dhamtari & 33 & 3 & 22 \\
\hline $\mathbf{4 .}$ & Janjgir-Champa & 42 & 4 & 38 \\
\hline $\mathbf{5 .}$ & Durg & 11 & 1 & 10 \\
\hline & Total & 162 & 15 & 138 \\
\hline
\end{tabular}

Table.2 Demand of agriculture machinery for different agriculture operation

\begin{tabular}{|r|c|c|c|c|}
\hline S. No. & Particular & $\begin{array}{c}\text { Demand of machinery } \\
\text { (Percentage })\end{array}$ & KYSK & Percentage \\
\hline $\mathbf{1}$ & Field preparation & 100 & 9 & 60 \\
\hline $\mathbf{2}$ & & 75 & 2 & 13 \\
\hline $\mathbf{3}$ & & 50 & 3 & 20 \\
\hline $\mathbf{4}$ & & 25 & 1 & 7 \\
\hline & \multicolumn{2}{|r|}{ Total } & 15 & \\
\hline $\mathbf{1}$ & Harvesting, Threshing \& & 100 & 10 & 67 \\
\hline $\mathbf{2}$ & Winnowing & 75 & 2 & 13 \\
\hline $\mathbf{3}$ & & 50 & 2 & 13 \\
\hline $\mathbf{4}$ & & 25 & 1 & 7 \\
\hline
\end{tabular}


Table.3 Demand of agriculture machinery in season wise

\begin{tabular}{|c|c|c|c|}
\hline S. No & Season & KYSK & Percentage \\
\hline & Kharif (Percentage) & & \\
\hline 1 & 100 & 11 & 73.33 \\
\hline 2 & 75 & 1 & 6.67 \\
\hline 3 & 50 & 3 & 20.00 \\
\hline 4 & 25 & 0 & 0.00 \\
\hline \multicolumn{2}{|r|}{ Total } & 15 & \\
\hline \multicolumn{2}{|r|}{ Rabi } & & \\
\hline 1 & 100 & 8 & 53.33 \\
\hline 2 & 75 & 1 & 6.67 \\
\hline 3 & 50 & 5 & 33.33 \\
\hline 4 & 25 & 1 & 6.67 \\
\hline \multicolumn{2}{|r|}{ Total } & 15 & \\
\hline
\end{tabular}

Table.4 Gap of Demand and Supply of KYSK

\begin{tabular}{|l|l|l|l|l|l|l|}
\hline S. No. & $\begin{array}{l}\text { Demand } \\
\text { level(Percent) }\end{array}$ & $\begin{array}{l}\text { Perception } \\
\text { by KYSK } \\
\text { owner }\end{array}$ & $\begin{array}{l}\text { Demand } \\
\text { (Percent) }\end{array}$ & $\begin{array}{l}\text { Supply } \\
\text { level } \\
\text { (percent) }\end{array}$ & $\begin{array}{l}\text { Perception } \\
\text { by KYSK } \\
\text { owner }\end{array}$ & $\begin{array}{l}\text { Supply } \\
\text { Percent }\end{array}$ \\
\hline 1. & $75-100$ & 13 & 86 & $75-100$ & 12 & 80 \\
\hline 2. & $50-75$ & 2 & 14 & $50-75$ & 2 & 13 \\
\hline 3. & $25-50$ & - & - & $25-50$ & 1 & 7 \\
\hline 4. & $0-25$ & - & - & $0-25$ & - & - \\
\hline & Total & 15 & 100 & & 15 & 100 \\
\hline
\end{tabular}

Table.5 Problems in hiring the machines from KYSK

\begin{tabular}{|c|l|c|c|}
\hline S. No & \multicolumn{1}{|c|}{ Problem } & Perception & Percentage \\
\hline $\mathbf{1}$ & Timely unavailability of implements & 38 & 27.54 \\
\hline $\mathbf{2}$ & High Hiring charges by KYSK & 20 & 14.49 \\
\hline $\mathbf{3}$ & Discriminate charge by KYSK & 25 & 18.12 \\
\hline $\mathbf{4}$ & Overlapping of farmer operation & 5 & 3.62 \\
\hline $\mathbf{5}$ & None of any problem & 90 & 36.23 \\
\hline & Total & 138 & 100 \\
\hline
\end{tabular}




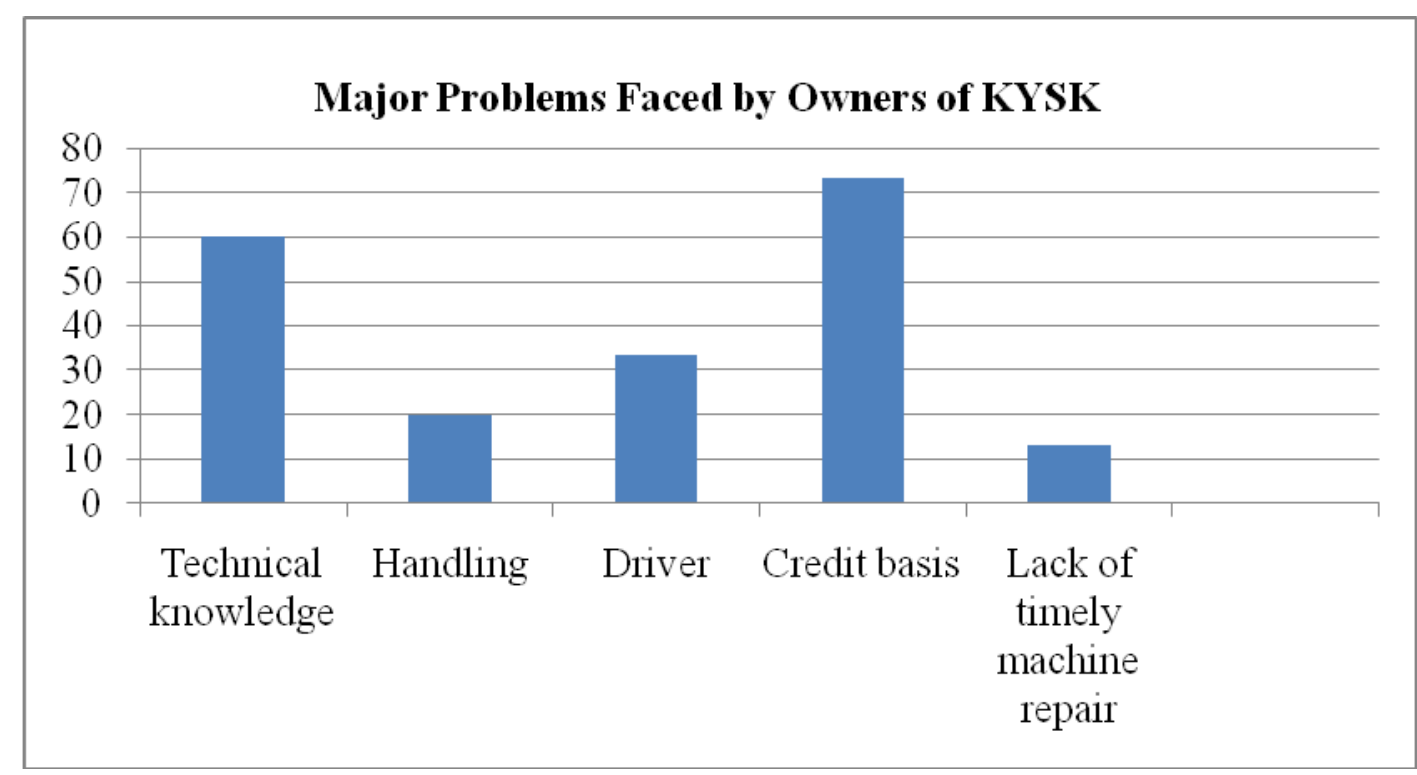

Fig.1 Problems faced by KYSK

Problems in hiring the machine from KYSKs on timely non-availability of machine/ implements from KYSK which was reported by 27.54 percent farmers. While discrimination on rates charged by owners of KYSK from framer to framer that was another major problem faced by farmers and reported by $18.12 \%$ farmers. Some of the farmers have also reported that rate charges was comparatively more than that of hiring rate charges by private owner of KYSK, i.e. reported by $14.49 \%$ farmers.

\section{References}

Hiremath, G.M. and Prashuanth, J. (2016).Constraints of Farmers in Utilizing Custom Hiring Service(CHS) of Tractor Based Farm Machineries -
An Analysis. International Journal of AgriculturalScience and Research,6(1): 217-220

Ranade D H , Chourasia M C , Shrivastava MK and Patidarl D (2006) Improved tools and scope for their custom hiring in malwa region - a case study. Agril Engg Today30 (1-2): 28-31.

Singh, B. K., Verma, A. R. and Kumar, Y. (2001). Agricultural Mechanization. Agro India, 6(2):13-17.

Verma S R (2005) Impact of agricultural mechanization on production, productivity, cropping intensity, income generation and employment of labor. Available at http://www.agricoop.nic.in/Farm\%20M ech.\%20PDF/contents.htm

\section{How to cite this article:}

Sursen Kumar and Pramita Baghel. 2020. Constrains and Gap between Existing and Demanded Service by Farmers in Utilizing Krishi Yantra Seva Kendra of Chhattisgarh Plain. Int.J.Curr.Microbiol.App.Sci. 9(07): 147-151. doi: https://doi.org/10.20546/ijcmas.2020.907.017 